\title{
Professional Portrait of History Teacher in Coordinates of Modern Russian Historical Education
}

\author{
Sinitzyn Oleg Vladimirovich ${ }^{1}$, Valiakhmetov Albert Nailevich ${ }^{1} \&$ Yuzmukhametova Landysh Nurgayanovna $^{1}$ \\ ${ }^{1}$ Kazan Federal University, 18 Kremlyovskaya St., Kazan, 420008, Republic of Tatarstan, Russia \\ Correspondence: Sinitzyn Oleg Vladimirovich, Kazan Federal University, 18 Kremlyovskaya St., Kazan, 420008, \\ Republic of Tatarstan, Russia. E-mail: olvsin@yandex.ru
}

Received: July 17, 2019

Accepted: October 10, 2019

Online Published: October 28, 2019

doi:10.5430/ijhe.v8n7p23

URL: https://doi.org/10.5430/ijhe.v8n7p23

\begin{abstract}
Classical background, topics of schooling history in high school and university bring attention to the existence of global challenges of the 21 st century common today. These calls necessitate the creation of new historical study from the younger contemporaries allowing to enter consciously the real world of the people living before and near it, able to analyze historical events, owning proper, commercial, socio-political knowledge, valuing cultural traditions of other people. In the article elements of a professional representation of the history teacher of the 21 st century are discriminated from positions of modern historical and pedagogical approaches, it is determined that the main ways of development of professionalism are the scientific character of historical thinking of the teacher, development of individual style of teaching and participation in innovative activity. The practical value of results consists of the practical use of conscious need of the modern teacher of history for continuous professional self-improvement.
\end{abstract}

Keywords: teacher, history, personality, professional activity, system of values, pupils, individual style

\section{Introduction}

The most important factor of achievement of the goals of modernization of historical education in Russia is professional and personal readiness of teachers to apprehend new values of education, to provide changes in area of historical education content, in educational technologies, in ways of measurement of educational achievements, in the solution of all complex of the social and pedagogical tasks facing the teacher at modern school.

Training of teachers of history for modern Russian society demands comprehensive improvement of system of pedagogical education. Problems of training of the teacher of the new generation capable for active joining in realization of problems of modernization of the country in the 21st century are defined in the Strategy of development for Russia till 2020, in the Strategy of development of education in the Russian Federation until 2025 in the new Federal Law "About Education in the Russian Federation", in Federal state educational standards. Successful implementation of the program of modernization of the country will depend on level of training of teachers of history and social science, their abilities to build the activity according to international and domestic experience, accounting of a ratio of traditions and innovations in it.

The modern situation in education is interesting that the teacher of history should act in the conditions of social variability. In short terms ideas of the values system, conditions of the society development have changed. Modern processes make active problems of training of youth for life in the conditions of the new civilization which is based on a priority of value of human morals and culture. Processes of reforming of the society aren't complete. Success of reforms depends on educational policy, in particular, in the field of historical education; overcoming the crisis phenomena - on efficiency of educational process. In these conditions such line of the professional teacher as the creativity which is expressed in constant search of ways of development of educational process in the subject "history" becomes norm.

\section{Methods}

During the research the major factors providing efficiency of process of studying of history come to light. These steady factors define activity of the teacher of history and pupils. Process of training of history has multilevel character. At the first level it represents the content of historical education, activity of the teacher and process of the studying. At the second level it is presented by methodical problems, methods of teaching and ways of cognitive activity of the pupil. At 
the third level it is defined by set of historical tasks, methodical receptions and actions of the pupil with historical information.

Scientific-theoretical function is implemented through the system of the didactic categories reflecting specifics of an object of assimilation: "methods of teaching history", "structure of historical education", "subject "history", etc.

Theoretical methods allow to establish the new didactic facts, regularities and to develop the models of historical education adequate to modern conditions. The following methods belong to this group: studying of the scientific literature devoted to problems of studying of history (establishment of relevance of the subject); modeling of historical education taking into account sociocultural conditions and the educational program; problematical character (articulation of the problems of practice of teaching history requiring the solution); generalization and interpretation of experience of studying of history.

Theoretical-methodological basis of the research are works of both the Russian and foreign scientists. To the fundamental domestic works on historical education it is necessary to refer works by N.G. Dayri, P. A. Baranov, E.E. Vyazemsky, P. G. Postnikov, M. P. Studenikin. From foreign literature the researches by M.Ferro, J. Nicol, K. Lindberg and J. Vernon became the most important.

\section{Results}

In the standard of the higher pedagogical education the qualification characteristic which contains the description of readiness of the teacher for implementation and training, and bringing up of students taking into account specifics of the studied subject and also the list of the professional knowledge necessary for the solution of pedagogical, scientific and methodical and organizational and administrative tasks is defined. The professional portrait considers features of methodical experience, individuality and the identity of the teacher of history. From this point of view the professional portrait of the teacher of history reflects his individual abilities to the solution of pedagogical tasks in professional level. The professional, first of all, realizes sense of the activity, understands a role of a subject of history in development of identity of the pupil, realizes values of historical experience for knowledge of the present and forecasting of the future. The sense of history as subject is in the fact that the child has to learn to estimate the present from the point of view of the past and to make the conscious choice between the good and evil, honor and disgrace, justice and injustice, legality and lawlessness. Without definite answer on these and other questions the professional portrait of the teacher of history will be incomplete.

In psychological and pedagogical literature several components of a professional portrait of the modern teacher with which the author in principle agrees and offer his own understanding in a projection to the teacher of history are allocated.

The first element of professionalism is valuable and semantic which reflects the system of values, installations and meanings of professional behavior. Formation of valuable orientations is an integral part of the identity of the person. During the transition crisis periods of development of the country and society there are new valuable orientations, new requirements and interests, and on their basis also the qualities of the personality characteristic of the previous period are reconstructed. Thus, valuable orientations act as personally forming system and are connected with development of consciousness, understanding of situation of the own "I" both as the teacher, and the pupil in the system of the educational relations. Value orientations belong to the most important components of structure of the personality on which extent of formation it is possible to judge the level of the personality formation. In modern Russia there is also a revaluation of values connected with refusal of a socialist way in economy and policy in the 1990s and transition to the capitalist market relations that also changes the valuable and semantic content of activity at which the material prosperity, first of all in terms of money becomes the major. But there are all the same also eternal values. It is known that teachers win wars, they train the generation, capable to move the country on the way of prosperity, ready to rise in case of need in defense of the homeland. The teacher has to both teach and bring up the citizen. And in it there is one of the main missions of the teacher of history.

The next one is a motivational component which consists available motives of achievements, realization of creative potential and individual success both professional and personal. The motivation is considered as one of key elements of formation of cognitive interest to educational activity, in this case on history.

Now there is a set of receptions and technologies of motivation: it is and demonstration of photos, portraits, pictures, schemes, cards, viewing of video fragments from documentary and feature films, establishment of intersubject communications with literature, geography, social science, informatics and so on, but nevertheless as the most effective reception of development of motivation most of researchers recognize the fascinating, emotional story, the 
teacher's explanation. It is reached by full-time employment of the teacher over increasing the professional skill, studying of the latest scientific works and historical documentary sources, works of art, Internet materials, etc.

The cognitive component of professionalism can be presented by the individual system of knowledge, abilities, and actions of the teacher of history. In this component of professional consciousness of the teacher, it is necessary to distinguish process of self-knowledge and result - the system of knowledge of himself induced at "image I" as the professional teacher who is the generalized system of representations of the subject about himself which is formed as a result of processes of understanding of himself in three complementary and crossed systems: in pedagogical activity, in pedagogical communication and in personal development. "An image I" of the teacher has mainly cognitive character and is rather steady unit though, certainly, to subject periodic fluctuations under the influence of internal and external factors according to sociocultural and regional conditions and type of the educational program realized by this establishment and the specific teacher of history. The cognitive component is represented in structure of consciousness as leading.

Procedural and methodical component of professionalism is in the developed abilities providing modeling, design, designing and implementation of projects of methodical activity. In Kazan Federal University within priority activities the Strategic Academic Unit (SAU) of the humanitarian direction "Teacher of the 21st Century" on the basis of Institute of Psychology and Education is created. The purpose of creation and development of SAE "Quadrature of Transformation of Pedagogical Education - 4T" are development of the concept of the reflexive and the research focused pedagogical education, design and realization of new structurally functional model of training of the teacher at the classical university: the transforming student, education transformation, the transforming teacher, transformation of pedagogical education. Getting by students historians the courses "Theory and Technique of Training of History", "Technique of Training and Education" is directed to giving to the future teachers the knowledge of not only theoretical bases of a modern technique of history, but also development of the competences necessary for ensuring high learning efficiency for a subject; formation of readiness for application of modern techniques and technologies of conducting educational activities for the subject "History" in institutions of the general secondary education and for implementation of cultural and educational activity. Achievement of this standard purpose is promoted by the appropriate pedagogical technologies strengthening a practical component. From 180 classroom hours on this discipline, 108 is taken on the laboratory occupations paying special attention to performances of students with the general and problem analysis of lessons, carrying out trial lessons, application of evident tutorials, to working methods with historical sources and documents, with fiction, to the analysis of modern school textbooks of history and the presentation by students of their own textbook at one of history courses. Forms of control of independent work when carrying out a practical training are a business game on the subject "Major Factors of Process of Training of History", the presentation of students on the subject "Activity of the Teacher and Pupils", modeling of a lesson of history by students of the subject "Lesson of History and Training of the Teacher for It". Such practical preparation and learning of this discipline by students precede student teaching in the high school passing on perineal and final courses during which the common cultural, professional and special competences acquired by students during classroom and independent work of bachelors at the university are individually estimated.

Integrative indicator of professionalism of the teacher of history is the individual style of activity, including emotionality, judiciousness, methodical, improvisation, an innovation. This indicator is mostly worked out in the psychological and pedagogical plan and also in detail that is on specialization of the teacher of history of the 21 st century.

But there are demanded models of modern approaches to training of teachers of history in the Russian Federation, proceeding from all listed above components.

\section{Discussion}

The problem touched in this research was considered in domestic historical and pedagogical science generally in respect of the analysis of the general aspects of a professional portrait of the modern teacher, and to a lesser extent, teachers of history.

L.A. Kabanina's, O. A. Lapina's, G. V. Sorokina's researches are directed to studying of substantial and technological aspects of formation of professional activity (portrait) of the teacher.

At the beginning of the 21 st century there is a transition to the personal focused system of development of the personality. In this connection, there is a number of the researches directed to studying of style features of identity of the person. Such research is the manual for students of pedagogical higher education institutions by G.A. Berulava "Style of identity: theory and practice". In this work the style is considered as the characteristic of the behavior of the 
person caused by features of its psychological state. V.P. Bezdukhov in the research "Theoretical Problems of Formation of Humanistic Style of Pedagogical Activity of Future Teacher" has considered questions of professional and pedagogical training of the teacher from the humanistic point of view.

As it was already noted, from modern researches on questions of training of the teacher of the history of the XXI century it is necessary to allocate especially P.A. Baranov, E.E. Vyazemsky, O. Yu Strelova, P.G. Postniky's works. Their works highlight the features of professional activity of the teacher of history of modern high school of Russia.

\section{Conclusions}

Authors of the article offer a professional portrait of the teacher of history of the 21 st century, proceeding from the developed option of model of training of the graduate in the Pedagogical education direction (History profile) according to the main requirements of Federal State Educational Standard of the higher education of 2018:

The graduate who has mastered the program of a bachelor degree has to have the following professional competences corresponding to a type of professional activity by a code of the professional standard 01.001 Science and education "The teacher (pedagogical activity in the sphere of the main general education).

Module: Subject training "History (general history, history of Russia)",

Labor actions

PC-1. Readiness to realize educational programs for ancient history, history of the Middle Ages, a modern history, history of Russia (VIII-XIX centuries) according to requirements of educational standards

PC-2. Ability to apply a conceptual framework of historical knowledge and receptions of the historical analysis to disclosure of essence and value of events and the phenomena of the past and the present

PC-3. Using together with students the sources of historical information for the solution of practical or informative tasks, in particular, ability to work with written, graphic and material historical sources, to understand and interpret information which is contained in them.

PC-4. Formation at students the culture of references to sources of publication, citing, comparison, dialogue with the author, prevention of copyright infringement.

PC-5 Ability of using of modern methods of a historical research, the theory and technology of training and diagnostics in the field of history.

PC-6. Ability to solve problems of education and spiritual and moral development of students in educational and extracurricular activities on history.

PC-7. Formation at students respect for the world and domestic historical heritage, culture of their own and other people; readiness to apply historical knowledge for identification and preservation of historical and cultural monuments of the country and the world.

PC-8. Readiness to apply historical knowledge to judgment of public events and the phenomena of the past and the present.

PC-9. Encouragement of individual and collective research creativity of students in the field of history.

Necessary abilities PC-10. To own methods and methods of training of national and general history.

PC-11. To use special correctional methods of training for children with limited opportunities of health

PC-12. Carrying constant work with families of students and local community on formation of historical consciousness, fixing the general and special in world, regional and national history.

PC-13. To localize a chronological framework and border events of historical eras, the main stages of national and general history in time; to correlate chronology of history of Russia and general history.

PC-14. To use the historical card as a source of information on resettlement of human 
communities, an arrangement of civilizations and the states, places of the major historical events.

PC-15. To systematize the historical material which is contained in educational and additional literature on national and general history

Necessary knowledge $\quad$ PC-16. Basic historical knowledge about the main stages and regularities of development of human society from antiquity up to now

PC-17. Complete ideas of a historical way of mankind, different people and states as necessary basis of outlook and knowledge of modern society; about continuity of historical eras and the continuity of historical processes; about the place and a role of Russia in world history

PC-18. Theory and technique of teaching history

PC-19. To define the place of historical events in time, to explain sense of the basic chronological historical concepts, terms.

PC-20. Causes and effects of key events of national and general history.

Other characteristics $\quad$ PC-21. Respect for legal, moral and ethical standards, requirements of professional ethics

\section{Acknowledgements}

The work is performed according to the Russian Government Program of Competitive Growth of Kazan Federal University.

\section{References}

AbdalinaL. (2008). Professionalism of the teacher: components, evaluation criteria. the Higher education in Russia, 10, 146-148.

Adolphus, V. A. (2007). About a technique of improvement of pedagogical skill, Education today, 9, 35-37.

Baranov, P. A. (2001). About tendencies of development of modern school historical education, Teaching history and social science at school, 3, 21-26.

Berulava, G. A. (2001). Style of identity: theory and practice: Study guide. G.A. Berulava. M.: Ped. society of Russia, 236.

Bezdukhov, V. P. (1992). Theoretical problems of formation of humanistic style of pedagogical activity of future teacher: Study guide. Samara, 104.

Dayri, N. G. (1978). Modern requirements to a history lesson. Moscow, 182.

Federal laws. (2018). Orders and Resolutions of the Government of the Russian Federation in the fields of education and sciences//http://www.rr-info.ru/normativno-pravovaya-informaciya/2035.html (Date of the address: 10/14/2018).

Ferro, M. (1992). How talking about history with children in the different countries of the world. the tr. from French. Moscow: The higher school, 351.

Kabanina, L. A. (2000). Formation of creative style of pedagogical activity at students of teacher training University. Saratov, 171.

Kodekova, G., Mukatayeva, K., Korvyakov, V. \& Auyezova, Z. (2018). Model of developing professional thinking in modern education conditions, Opción, 34(85-2), 458-478.

Lapina, O. A. (2004). Identity of the teacher: formation problems. Irkutsk: Publishing house of Irkutsk state. ped. un-t. 238.

Lindenberg, K. (1997). Training of history. Parsifal; Russian word, 192.

Luo, C., Li, M., Peng, P. \& Fan, S. (2018). How Does Internet Finance Influence the Interest Rate? Evidence from Chinese Financial Markets, Dutch Journal of Finance and Management, $2(1)$, 01. https://doi.org/10.20897/djfm/89590

Nagayeva, G. (2016). History of Russia in the USE format. The latest time: The manual. Rostov on Don: Phoenix, 94 p. http://znanium.com/bookread2.php?book=908188. 
Nicol, J. (2001). Craft of the teacher of history: The manual. the tr. from English, Yaroslavl, 272.

Postnikov, P. G. (1998). A professional portrait of the teacher of history. Training of teachers and development of system of professional development in the field of teaching history at high school: Materials of the international seminar, Yekaterinburg, 158-160.

Rodionova, N. D. (2007). Methodological culture of the teacher: practice of improvement of professional competence: educational and methodical grant. Orenburg: Publishing house GU "RTsRO", 75.

SAFDARI, M., ARAB, B. A. \& BAGHERI, G. A. (2013). Realization of economic justice through teleworking, UCT Journal of Management and Accounting Studies, 1(1), 11-13.

Sorokina, G. V. (2004). Formation of individual style of professional activity of future teacher. Volgograd, 189.

Studenikin, M. T. (2000). Technique of teaching history at school. Moscow: Vlados, 240.

Suleri, J. \& Cavagnaro, E. (2016). Promoting pro-environmental printing behavior: The role of ICT barriers and sustainable values, International Journal of Education and Development using ICT, 12(2). https://doi.org/10.20897/lectito.201638

Verbitsky, A. A. (2008). Reforming of education in Russia and Bologna Process, Higher education today, 11, 51-55.

Vernon, J. (2011). The State They Are In: History and Public Education in England. https://www.historians.org/publications-and-directories/perspectives-on-history/march-2011 /the-state-they-are-in-history-and-public-education-in-england (Date of access: 14.10.18)

Vyazemsky, E. E. \& Strelova, O. Yu. (2017). Professional competence of the teacher of history, Teaching history and social science at school, 4, 44-50.

Vyazemsky, E. E. (2001). Historical science and historical education: some problems of the theory and methodology, Teaching history and social science at school, 3, 13-21. 